\title{
KEANEKARAGAMAN FORAMINIFERA BENTIK TELUK BALIKPAPAN, PROVINSI KALIMANTAN TIMUR
}

\section{DIVERSITY OF BENTHIC FORAMINIFERA AT BALIKPAPAN BAY, EAST KALIMANTAN}

\author{
MASTUTI WIDIANINGSIH \\ Institut Ilmu Kesehatan Bhakti Wiyata, Jalan KH. Wakhid Hasyim No. 65, Kediri, Jawa Timur \\ Email : widianingsihmastuti910224@gmail.com
}

Diterima 21 Februari 2017. Disetujui 28 September 2017

\section{INTISARI}

Teluk Balikpapan menjadi salah satu lokasi pengambilan sampel sedimen untuk penelitian foraminifera bentik. Tujuan penelitian ini adalah mengetahui keanekaragaman foraminifera bentik di perairan Teluk Balikpapan, Kalimantan Timur. Sampel dipilih pada kedalaman o-20 m, kemudian dikelompokkan menjadi 4 kedalaman, yaitu 0-5 m, 6-10 m, 11-15 m, dan 16-20 m. Sebanyak 1553 spesimen yang diperoleh berasal dari 66 spesies, 7 ordo, dan 17 famili yang berbeda. Asterorotalia trispinosa merupakan spesies dengan kemelimpahan tertinggi, diikuti oleh Rotalia sp.1, Rotalia sp.2, dan Trichammina nana. Indeks keanekaragaman dari masing-masing titik sampling berbeda, yaitu 8 titik memiliki keanekaragaman stabil, 11 titik moderat, dan 1 titik tidak stabil. Kondisi tersebut dipengaruhi oleh kedalaman, kecerahan, temperatur, $\mathrm{pH}$, turbiditas, salinitas, dan $\mathrm{DO}$ yang berbeda pada setiap titik pengambilan sampel sedimen.

\section{Kata kunci : keanekaragaman, foraminifera, Teluk Balikpapan}

\begin{abstract}
Balikpapan Bay is one of locations of sampling sediments for the study of benthic foraminifera. The objective of this research was to determine the diversity of benthic foraminifera at different depths at Balikpapan Bay, East Kalimantan. Samples was selected at depth of o-20 m, then divided into 4 depths, o-5 m, 6-10 m, 11-15 m, and 16$20 \mathrm{~m}$. A total of 1553 specimens were obtained from 66 species, 7 ordo, and 17 family. Asterorotalia trispinosa is a species with the highest of abundance, that followed by Rotalia sp.1, Rotalia sp.2, and Trichammina nana. The diversity index of each sampling point was different, 8 points have stable diversity, 11 moderate points, and 1 unstable point. This condition were influenced by depth, brightness, temperature, $\mathrm{pH}$, turbidity, salinity, and $\mathrm{DO}$ at each sediment sampling point.
\end{abstract}

Keywords : diversity, foraminifera, Balikpapan Bay

\section{PENDAHULUAN}

Teluk Balikpapan dipengaruhi oleh kondisi lingkungan di bagian daratan dan lautan sekitar Selat Makasar. Dinamika kedua lingkungan tersebut secara tidak langsung akan berpengaruh pada kehidupan foraminifera bentik. Foraminifera bentik menjadi salah satu jenis organisme protozoa bercangkang yang hidupnya relatif menetap dan memiliki kontribusi dalam pelestarian terumbu karang (Yamano et al., 2000) di Teluk Balikpapan. Foraminifera bentik cepat merespon perubahan lingkungan karena pola hidupnya yang menetap sehingga dapat dijadikan indikator kualitas perairan (Noortiningsih et al., 2008; Natsir, 2010; Toruan et al., 2013).

Kemelimpahan foraminifera bentik dipengaruhi oleh faktor kecerahan, $\mathrm{pH}$, turbiditas, salinitas, kadar oksigen, dan kedalaman (Boltovskoy and Wright, 1976; Gustiani et al, 2005). Peningkatan kedalaman akan mengakibatkan penurunan jumlah dan jenis foraminifera bentik (Dewi dan Saputro, 2013). Sebanyak 133 spesies didapatkan dari sampel sedimen perairan Teluk Sepi pada kedalaman 1-35 m (Auliaherliaty, 2004). Penelitian Nurruhwati et al. (2012) di Teluk Jakarta menunjukkan adanya 85 spesies foraminifera bentik di Teluk Jakarta pada kedalaman 1-30 m. Kedua hasil tersebut memberikan gambaran bahwa kedalaman pengambilan sampel sedimen dapat menjadi salah satu faktor penentu keanekaragaman foraminifera bentik.

Selain itu, di tahun 2011, Adisaputra melakukan identifikasi sampel sedimen perairan Teluk Balikpapan dengan kedalaman pengambilan sampel 18-561 m dan didapatkan 195 spesies. Penelitian tentang keanekaragaman ini bertujuan untuk melihat pengaruh kedalaman yang berbeda pada perairan Teluk Balikpapan terhadap keanekaragaman jenis foraminifera bentik.

\section{MATERI DAN METODE}

Berikut adalah tahapan analisa keanekaragaman foraminifera bentik. 


\section{Pengambilan dan Pengelompokkan Sampel Sedimen}

Sampel yang digunakan merupakan sampel sedimen hasil cucian (washed residu) yang telah tersedia di Pusat Penelitian dan Pengembangan Geologi Kelautan (PPPGL) untuk berbagai analisa. Sampel tersebut diambil oleh Tim Penelitian Lingkungan dan Kebencanaan Geologi Kelautan, Pusat Penelitian dan Pengembangan Geologi Kelautan (PPPGL) di perairan Teluk Balikpapan. Sampel sedimen diambil menggunakan grab sampler (pemercontoh comot) pada lebih dari 50 titik lokasi secara acak berdasarkan pola batimetri (peta kedalaman laut yang berfungsi untuk mengetahui morfologi dasar laut dan kemantapan lereng dasar laut) dan mewakili daerah penelitian serta dengan titik koordinat pengambilan sampel yang berbeda-beda (Tabel 1). Dari 50 titik lokasi pengambilan sampel, kemudian diambil titik pengambilan sampel secara acak dengan kedalaman yang berbeda yaitu kurang dari $40 \mathrm{~m}$.

Sampel yang diambil pada perairan Teluk Balikpapan, selanjutnya dikelompokkan menjadi 4 kedalaman, yaitu 0-5 m, 6-10 m, 11-15 m, dan 16-20 m. Pengelompokkan kedalaman tersebut didasarkan atas data sekunder berupa kedalaman pengambilan sampel foraminifera bentik. Dari masing-masing kelompok kedalaman tersebut selanjutnya diambil sebanyak 5 sampel sedimen untuk kemudian dilakukan analisis foraminifera

\section{Picking}

Picking bertujuan memisahkan spesimen foraminifera bentik dari sedimen atau material lainnya. Sampel sediaan ditimbang berat keringnya, kemudian dilakukan picking dengan menebarkan sedikit demi sedikit sampel pada picking tray. Sebelum ditebar, sampel sedimen dibagi menggunakan splitter bila volumenya besar. Pengamatan dilakukan dengan mikroskop binokular perbesaran 100x. Picking dilakukan secara terus menerus dengan kuas kecil (no. 1) yang terlebih dahulu dicelupkan dalam air sampai mendapatkan spesimen sebanyak 300. Masing-masing sampel dilakukan proses pengulangan picking sebanyak 3 kali. Spesimen hasil picking diletakkan pada assemblage slide yang telah diolesi tragacant gum. Assemblage slide terdiri dari 60 petak, masing-masing petak diisi dengan 5 spesimen.

\section{Koleksi}

Koleksi dilakukan dengan memindahkan spesimen foraminifera bentik hasil picking yang memiliki bentuk berbeda ke assemblage slide yang baru guna memudahkan proses identifikasi. Setiap kotak assemblage slide yang baru berisi minimal 2 spesimen yang sama, selanjutnya dilakukan pencatatan nomer sampel asal spesimen foraminifera yang telah dipindah ke assemblage slide untuk koleksi.

\section{Identifikasi}

Identifikasi dilakukan secara berurutan menggunakan kunci determinasi berupa buku acuan Barker (1960), Loeblich and Tappan (1994), serta
Yassini and Jones (1995) sampai diperoleh nama spesies. Setelah identifikasi, dilakukan penghitungan jumlah spesies pada masing-masing sampel sedimen untuk analisa data. Ciri-ciri yang diamati dari spesimen meliputi komposisi dan bentuk cangkang, bentuk dan jumlah kamar, jumlah puataran cangkang, ornamen cangkang, serta bentuk dan posisi apertura.

Setelah proses identifikasi selesai, kemudian dilakukan penghitung jumlah dari masing-masing spesies foraminifera. Data tersebut berguna untuk mengetahui indeks kemelimpahan tiap spesies pada masing-masing titik pengambilan sampel.

\section{Analisis Data}

\section{Kelimpahan (K)}

Menurut Bakus (1990), kelimpahan dapat dihitung dengan rumus berikut :

$$
K=\frac{\sum \text { spesies } / \text { plot }}{\text { sampel }(\text { gram })}
$$

\section{Indeks keanekaragaman $\left(\mathrm{H}^{\prime}\right)$}

Indeks keanekaragaman dihitung berdasarkan formulasi Shannon-Weaver (Bakus, 1990).

$H^{\prime}=-\sum p i \log p i$

$p=\frac{n i}{N}$

Keterangan :

$\mathrm{H}^{\prime}=$ Indeks keanekaragaman

$\mathrm{ni}=$ Jumlah jenis ke-i

$\mathrm{N}=$ Jumlah total individu

Jika :

1. $\mathrm{H}^{\prime}<1$, maka komunitas dalam kondisi tidak stabil

2. $1<\mathrm{H}^{\prime}<3$, maka komunitas dalam kondisi moderat

3. $\mathrm{H}^{\prime}>3$, maka komunitas dalam kondisi baik

\section{Indeks kemerataan ( $\left.\mathrm{J}^{\prime}\right)$}

Indeks kemerataan berkisar antara 0-1. Indeks kemerataan dihitung berdasarkan formulasi Pielou (Bakus, 1990).

$$
J^{\prime}=\frac{H^{\prime}\left(\log _{e}\right)}{\log _{e} S}
$$

\section{Keterangan :}

$\mathrm{J}^{\prime} \quad=$ Indeks kemerataan

$\mathrm{H}^{\prime} \quad$ = Indeks keanekaragaman

$\mathrm{S} \quad=$ Jumlah jenis

\section{Indeks dominansi (D)}

Indeks dominansi dihitung dengan menggunakan rumus berikut (Bakus 1990):

$$
\begin{aligned}
& D=1-C \\
& C=\sum p i^{2}
\end{aligned}
$$

Nilai indeks dominansi adalah $0-1$. Jika mendekati 1 maka ada spesies yang mendominasi, jika mendekati o maka hampir tidak ada individu yang mendominasi. 
Tabel 1. Pengelompokan Sampel Sedimen Teluk Balikpapan, Kalimantan Timur

\begin{tabular}{ccccc}
\hline Kelompok & No. Sampel & Lintang & Bujur & $\begin{array}{c}\text { Kedalaman Lokasi Pengambilan } \\
\text { Sampel (m) }\end{array}$ \\
\hline 1 & TB-01 & $-1,20220$ & 116,7657 & 1,5 \\
$(0-5 \mathrm{~m})$ & TB-02 & $-1,29590$ & 116,76627 & 2,9 \\
& TB-03 & $-1,35058$ & 116,77380 & 4,0 \\
& TB-04 & $-1,13977$ & 116,77067 & 4,0 \\
& TB-05 & $-1,23355$ & 116,76815 & 5,0 \\
$(6-10 \mathrm{~m})$ & TB-06 & $-1,29523$ & 116,88225 & 7,0 \\
& TB-07 & $-1,36207$ & 116,81405 & 7,5 \\
& TB-08 & $-1,39948$ & 116,76603 & 8,0 \\
3 & TB-09 & $-1,29270$ & 116,94348 & 9,5 \\
$(11-15 \mathrm{~m})$ & TB-10 & $-1,37955$ & 116,84058 & 12,0 \\
& TB-11 & $-1,31907$ & 116,82602 & 12,0 \\
& TB-12 & $-1,26315$ & 116,79992 & 14,0 \\
& TB-13 & $-1,21033$ & 116,77478 & 14,0 \\
4 & TB-14 & $-1,32925$ & 116,90197 & 16,0 \\
$(16-20 \mathrm{~m})$ & TB-15 & $-1,28007$ & 116,79020 & 16,0 \\
& TB-16 & $-1,25465$ & 116,79278 & 17,0 \\
& TB-17 & $-1,23660$ & 116,78988 & 18,0 \\
& TB-18 & $-1,17685$ & 116,77025 & 20,0 \\
\hline
\end{tabular}

Tabel 2. Param kualitas air di Teluk Balikpapan, Kalimantan Timur

\begin{tabular}{cccccccc}
\hline $\begin{array}{c}\text { No } \\
\text { Sampel }\end{array}$ & $\begin{array}{c}\text { Kedalaman } \\
(\mathrm{m})\end{array}$ & $\begin{array}{c}\text { Kecerahan } \\
(\mathrm{m})\end{array}$ & $\begin{array}{c}\text { Temperatur } \\
\left({ }^{\circ} \mathrm{C}\right)\end{array}$ & $\mathrm{pH}$ & $\begin{array}{c}\text { Turbiditas } \\
(\mathrm{NTU})\end{array}$ & $\begin{array}{c}\text { Salinitas } \\
(\%)\end{array}$ & $\begin{array}{c}\mathrm{DO} \\
(\mathrm{mg} / \mathrm{L})\end{array}$ \\
\hline TB-01 & 1,5 & & & & & & \\
TB-02 & 2,9 & 3,0 & 31,4 & 7,5 & 0,18 & 3,15 & 6,2 \\
TB-03 & 4,0 & 2,5 & 31,5 & 8,0 & 4,22 & 3,30 & 7,2 \\
TB-04 & 4,0 & 4,0 & 31,5 & 7,6 & 0,58 & 3,03 & 7,1 \\
TB-05 & 5,0 & 3,0 & 31,3 & 7,5 & 2,89 & 3,04 & 7,1 \\
TB-06 & 7,0 & 5,5 & 30,1 & 8,0 & 1,09 & 3,35 & 6,8 \\
TB-07 & 7,0 & 5,5 & 30,6 & 8,0 & 3,97 & 3,39 & 7,6 \\
TB-08 & 7,5 & 7,0 & 30,1 & 7,9 & 0,92 & 3,38 & 7,7 \\
TB-09 & 8,0 & 7,0 & 30,6 & 8,0 & 2,20 & 3,36 & 8,3 \\
TB-10 & 9,5 & 7,5 & 30,3 & 8,0 & 2,27 & 3,47 & 7,7 \\
TB-11 & 12,0 & 5,0 & 30,7 & 7,7 & 1,56 & 3,35 & 6,0 \\
TB-12 & 12,0 & 6,0 & 30,9 & 7,5 & 0,50 & 3,32 & 7,8 \\
TB-13 & 12,0 & 6,0 & 31,0 & 7,5 & 0,83 & 3,22 & 5,4 \\
TB-14 & 14,0 & 5,5 & 30,1 & 7,9 & 3,93 & 3,46 & 7,3 \\
TB-15 & 14,0 & 6,0 & 30,8 & 7,8 & 1,49 & 3,30 & 4,6 \\
TB-16 & 16,0 & 5,0 & 31,0 & 7,5 & 0,55 & 3,36 & 7,1 \\
TB-17 & 16,0 & 6,0 & 30,9 & 7,6 & 1,14 & 3,28 & 6,9 \\
TB-18 & 17,0 & 3,5 & 30,8 & 7,6 & 1,43 & 3,38 & 4,9 \\
TB-19 & 18,0 & 7,0 & 31,1 & 7,7 & 1,94 & 3,14 & 6,3 \\
TB-20 & 20,0 & 8,0 & 30,1 & 7,8 & 2,24 & 3,42 & 7,6 \\
\hline
\end{tabular}

\section{Korelasi Pearson (r)}

Korelasi Pearson digunakan untuk mengetahui besarnya hubungan antara indeks keanekaragaman jenis dengan param kualitas air yang meliputi kedalaman, kecerahan, temperatur, $\mathrm{pH}$, turbiditas, salinitas, dan DO (Tabel 2). Berikut rumus yang digunakan untuk menghitung nilai korelasi tersebut.

$$
r=\frac{\sum(x-\bar{x})(y-\bar{y})}{\sqrt{\sum(x-\bar{x})^{2} \sum(y-\bar{y})^{2}}}
$$

Keterangan :

$\mathrm{x} \quad=$ Indeks keanekaragaman $\left(\mathrm{H}^{\prime}\right)$

$\mathrm{y} \quad=$ Param kualitas air (kedalaman, kecerahan, temperatur, $\mathrm{pH}$, turbiditas, salinitas, dan $\mathrm{DO}$ )

\section{HASIL}

Keanekaragaman spesies pada perairan Teluk Balikpapan tersaji pada Tabel 4 dengan Asterorotalia trispinosa sebagai spesies dominan. Indeks keanekaragaman berbeda pada setiap titik pengambilan sampel. Sebanyak $(7)_{1}$ titik memiliki keanekaragaman foraminifera bentik yang stabil (lebih dari 3), 11 titik moderat (antara 1-3), dan 1 titik tidak stabil (kurang dari 1). Nilai indeks keanekaragaman 
Tabel 3. Nilai kelimpahan, indeks keanekaragaman jenis, indeks kemerataan, dan indeks dominansi

\begin{tabular}{cccccccc}
\hline No Sampel & $\begin{array}{c}\text { Kedalaman } \\
(\mathrm{m})\end{array}$ & $\sum$ Spesies & $\sum$ Individu & $\mathrm{K}$ & $\mathrm{H}^{\prime}$ & $\mathrm{J}$ & $\mathrm{D}$ \\
\hline TB-01 & 1,5 & 4 & 8 & 0,564 & 1,386 & 0,953 & 0,047 \\
TB-02 & 2,9 & 12 & 298 & 94,576 & 2,639 & 0,617 & 0,383 \\
TB-03 & 4,0 & 2 & 9 & 1,344 & 1,099 & 0,773 & 0,228 \\
TB-04 & 4,0 & 11 & 299 & 43,781 & 2,565 & 0,519 & 0,481 \\
TB-05 & 5,0 & 13 & 207 & 37,518 & 2,996 & 0,625 & 0,375 \\
TB-06 & 7,0 & 24 & 300 & 49,788 & 2,996 & 0,754 & 0,247 \\
TB-07 & 7,0 & 24 & 260 & 46,245 & 3,178 & 0,870 & 0,130 \\
TB-08 & 7,5 & 22 & 248 & 24,629 & 3,091 & 0,841 & 0,159 \\
TB-09 & 8,0 & 23 & 232 & 43,713 & 3,332 & 0,826 & 0,175 \\
TB-10 & 9,5 & 33 & 172 & 80,668 & 3,738 & 0,854 & 0,146 \\
TB-11 & 12,0 & 14 & 300 & 47,034 & 3,045 & 0,614 & 0,386 \\
TB-12 & 12,0 & 15 & 232 & 13,968 & 3,045 & 0,697 & 0,303 \\
TB-13 & 12,0 & 17 & 300 & 47,333 & 2,974 & 0,746 & 0,260 \\
TB-14 & 14,0 & 15 & 262 & 16,391 & 2,890 & 0,711 & 0,289 \\
TB-15 & 14,0 & 20 & 285 & 62,752 & 3,219 & 0,749 & 0,251 \\
TB-16 & 16,0 & 12 & 172 & 12,022 & 2,773 & 0,616 & 0,384 \\
TB-17 & 16,0 & 16 & 296 & 20,915 & 3,258 & 0,571 & 0,429 \\
TB-18 & 17,0 & 2 & 10 & 0,992 & 0,693 & 0,722 & 0,278 \\
TB-19 & 18,0 & 12 & 288 & 27,441 & 2,708 & 0,319 & 0,687 \\
TB-20 & 20,0 & 16 & 300 & 63,456 & 2,890 & 0,403 & 0,597 \\
\hline
\end{tabular}

berkisar antara 0-4. Indeks keanekaragaman tertinggi dimiliki oleh TB-10 dan terendah pada TB-18 (Tabel 3). Besarnya nilai korelasi Pearson berdasarkan variabel tersebut berturut-turut tercantum pada Gambar 1.
Beberapa hasil penelitian menunjukkan bahwa kecerahan, turbiditas, DO, dan COD (Rositasari 2006; Renema, 2008), serta pH (Nooijer et al., 2009) akan mempengaruhi keanekaragaman foraminifera bentik.

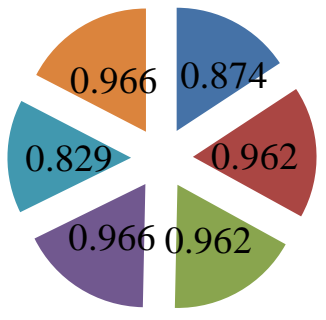

Gambar 1. Diagram Korelasi Pearson

\author{
- Kedalaman \\ - Kecerahan \\ Temperatur \\ pH \\ Turbiditas \\ - Salinitas
}

\section{PEMBAHASAN}

Umumnya foraminifera bentik banyak ditemukan pada sedimen pasiran (Natsir, 2010). Sebanyak 66 spesies didapatkan dari hasil koleksi sampel sedimen Teluk Balikpapan. Spesimen tersebut berasal dari 7 ordo dan 17 familia. Asterorotalia trispinosa (ordo Rotaliida) merupakan spesies yang ditemukan hampir pada setiap titik pengambilan sampel dengan jumlah keseluruhan 1553 (Tabel 4). Spesies dengan kepadatan terendah adalah Quinqueloculina philippinensis, Quinqueloculina reticulata, Quinqueloculina sp., dan Ammonia sp. (hanya 1 spesimen).

Kemelimpahan ordo Rotaliida merupakan salah satu ciri perairan laut normal dengan kadar kalsium karbonat dan kecerahan yang cukup tinggi (Adisaputra and Hendrizan, 2011). Keseluruhan titik pengambilan sampel sedimen yang didominasi Asterorotalis trispinosa (Tabel 4) menandakan titik tersebut merupakan jenis perairan terbuka dengan arus yang kencang (Gustiani and Usman, 2008; Rositasari, 2011). Selain itu, morfologi Asterorotalis trispinosa yang memiliki 3 duri dapat mempermudah spesies tersebut berpindah temt (daya adaptasi) ketika terjadi perubahan lingkungan (Adisaputra and Hendrizan, 2011).

Tingginya keanekaragaman yang dapat terawetkan dalam sedimen dipengaruhi oleh faktor salinitas. Kadar salinitas yang tinggi akan membantu proses sekresi kalsium karbonat sebagai senyawa pembentuk cangkang foraminifera bentik melalui proses kalsifikasi (Natsir, 2010). Terhambatnya kalsifikasi akan mengakibatkan cangkang yang terbentuk tidak sempurna sehingga memicu penurunan total foraminifera bentik yang dapat terawetkan dalam sedimen (Geslin et al., 2002; Vilela et al., 2004; Rositasari, 2006; Mojtahid et al., 2006; Burone et al., 2007; Brouillette, 2009; Buosi et al., 2010; Colon and Hallock, 2010; Denoyelle et al., 2010).

Nilai DO berbanding lurus dengan tingkat kecerahan dan berbanding terbalik dengan turbiditas. Tingkat kecerahan yang rendah mengakibatkan sinar matahari tidak dapat menembus perairan meskipun pada umumnya sinar matahari dapat mencapai 


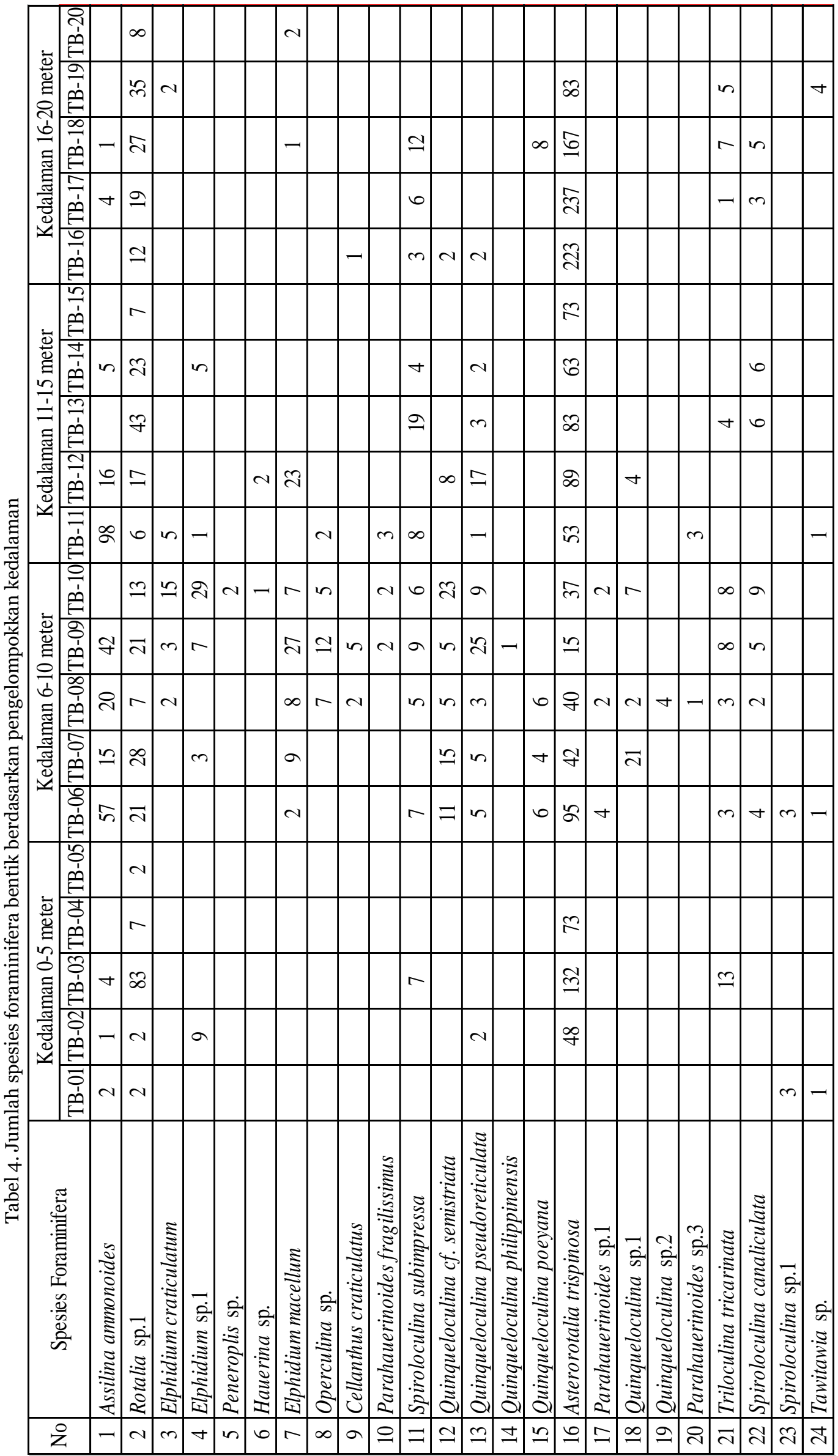




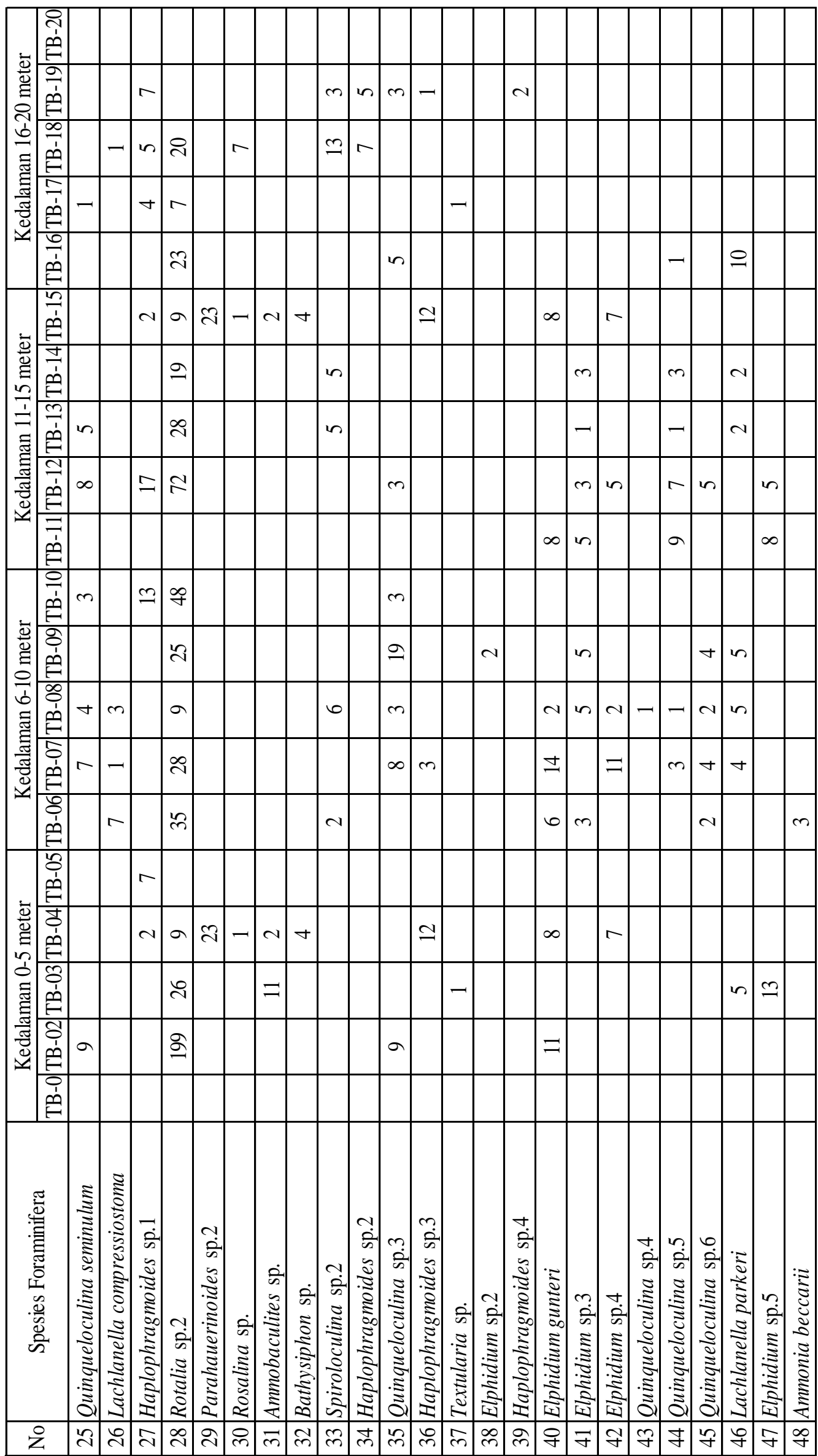




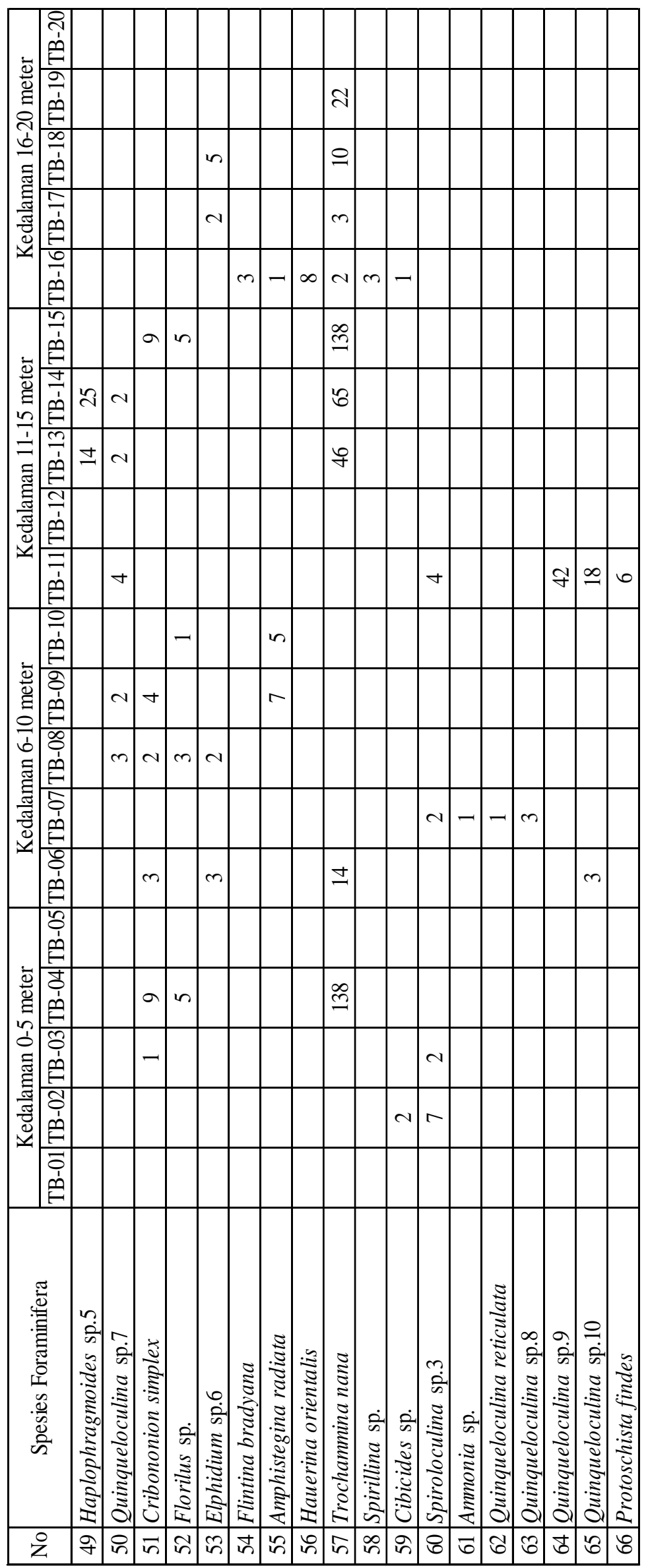


kedalaman $200 \mathrm{~m}$. Berdasarkan ketentuan Mendes et al. (2004), indeks keanekaragaman titik pengambilan sampel sedimen Teluk Balikpapan dapat dikatakan bervariasi, dari yang terendah yaitu 0,693 dan tertinggi 3,378 (Tabel 3). Berdasarkan hasil penelitian Boltovskoy and Wright (1976) menunjukkan bahwa penurunan tingkat kecerahan akan mempengaruhi indeks keanekaragaman jenis foraminifera bentik. Penurunan kadar DO terjadi akibat berkurangnya jumlah tumbuhan air yang berpengaruh terhadap distribusi dan kemelimpahan foraminifera bentik. Baku mutu kadar DO bagi biota laut berdasarakan Keputusan Menteri Lingkungan Hidup Tahun 2004 adalah lebih dari $5 \mathrm{mg} / \mathrm{L}$. Tingginya nilai turbiditas (kekeruhan) akan berpengaruh pada aktivitas fotosintesis tumbuhan air dalam menghasilkan nutrien dan oksigen guna mencukupi kebutuhan foraminifera bentik yang akan berpengaruh terhadap pembentukan sedimen dan penentu kualitas perairan (Boyd et al., 2002). Nilai turbiditas titik pengambilan sampel pada penelitian ini berkisar antara 0,18-4,22 NTU (Tabel 2). Nilai tersebut dianggap baik bagi kehidupan laut biota laut karena kurang dari 5 NTU (Keputusan Menteri Lingkungan Hidup, 2004).

Indeks kemerataan yang diperoleh pada perairan Teluk Balikpapan berkisar antara 0,319-0,953. Nilai indeks kemerataan o berarti rendah dan nilai indeks kemerataan 1 berarti tinggi (Drinia et al., 2004; Burone and Pires-vanin, 2006). Nilai tersebut menunjukkan persebaran foraminifera bentik di perairan Teluk Balikpapan tidak merata pada saat pengambilan sampel sedimen yang dapat dipengaruhi oleh faktor kedalaman dan arus perairan. Lokasi dengan kedalaman kurang dari $5 \mathrm{~m}$ umumnya sangat dipengaruhi oleh arus perairan, sehingga foraminifera bentik dapat tersebar merata (Gustiani et al., 2005). Penurunan populasi foraminifera bentik mengakibatkan terjadinya penurunan kualitas perairan bagi pertumbuhan dan proses kalsifikasi terumbu karang (Hallock et al., 2003). Secara umum, peningkatan level kedalaman akan mengurangi jumlah dan jenis foraminifera bentik (Murray, 2006). Rositasari (2011) dalam hasil penelitian perairan Teluk Jakarta menyatakan bahwa pengaruh sedimentasi daratan dan kedalaman laut berbanding terbalik dengan jumlah foraminifera.

Nilai korelasi Pearson adalah nilai yang menyatakan hubungan antara keanekaragaman dengan param kualitas perairan Teluk Balikpapan(Gambar 1). Beberapa hasil penelitian menunjukkan bahwa kecerahan, turbiditas, DO, dan COD (Rositasari 2006; Renema, 2008), serta pH (Nooijer et al., 2009) akan mempengaruhi keragaman foraminifera bentik. Hasil perhitungan korelasi Pearson menunjukkan terdapat hubungan yang kuat antara faktor fisika perairan laut dengan keragaman spesies foraminifera di Perairan Teluk Balikpapan (o,81-0,99).

\section{SIMPULAN}

Teluk Balikpapan memiliki tingkat keanekaragaman yang tidak stabil akibat pengaruh kedalaman, kecerahan, temperatur, $\mathrm{pH}$, turbiditas, salinitas dan DO, dengan nilai korelasi Pearson 0,81-0,99. Spesies dominan pada perairan tersebut adalah Asterorotalia trispinosa dengan jumlah 1553 spesimen.

\section{KEPUSTAKAAN}

Adisaputra, M.K., M. Hendrizan. 2011. Foraminifera Perairan Teluk Balikpapan, Kalimantan Timur : Lingkungan Pengendapan dan Pengaruhnya. J. Geologi Kelautan 9(2): 119-134.

Auliaherliaty, K.T. Dewi, Y.A. Priohandono. 2004. Foraminifera di Teluk Sepi-Blongas, Lombok Selatan, Nusa Tenggara Barat dan Kaitannya dengan Faktor Lingkungan. J.Geologi Kelautan. 2(3): $1-8$.

Bakus, J.G. 1990. Quantitative Ecology and Marine Biology. Departement of Biological Sciences. University of Southern California. Los Angeles.

Barker, R.W. 1960. Taxonomic Notes. Paleontologi. USA.

Boltovskoy, E., R. Wright. 1976. Recent Foraminifera. Dr. W. Junk b.v. Publishers-The Hague. Buenos Aires.

Boyd, C.E., C.W. Wood, T. Thunjai. 2002. Aquaculture Pond Bottom Soil Quality Management. Pond Dynamic/ Aquaculture Collaborative Research Support Programe. Oregon State University. Oregon.

Brouillette, E. 2009. An Experiment Approach to Understand The Responses of Benthic Foraminifera to $\mathrm{Cd}, \mathrm{Pb}, \mathrm{Hg}$ and $\mathrm{Zn}$. Thesis paper. The University of Georgia. 8op.

Buosi, C., F. Frontalini, S. Da Pelo, A. Cherchi, R. Coccioni, and C. Bucci. 2010. Foraminiferal Proxies for Environmental Monitoring in The Polluted Lagoon of Santa Gilla (Cagliari, Italy). Present Environment and Sustainable Development 14: 91103.

Burone, L., A.M.S. Pires-vanin. 2006. Foraminiferal Assemblages in Ubatuba Bay, South-Eastern Brazilian Coast. Scientia Marina 70: 203-217.

Burone, L., P. Valente, A.M.S. Pires-Vanin, S.H. De Mello, E. Sousa, M.M. Mahiques, E. Braga. 2007. Benthic Foraminiferal Variability on a Monthly Scale in a Sub-Tropical Bay Moderately Affected by Urban Sewage. J. Scientia Marina 71(4): 775-792.

Colon, M.M., P. Hallock. 2010. Pre-liminary Survey on Foraminiferal Responses to Pollutants in Torrecillas Lagoon Puerto Rico. Carribean J. Sci. 46(1): 106111.

Denoyelle, M., F.J. Jorissen, D. Martin, F. Galgani, J. Mine. 2010. Comparison of Benthic Foraminifera and Macrofaunal Indicators of The Impact of Oil Based Drill Mud Disposal. J. Marine Pollution Bulletin 60(11): 2007-2021.

Dewi, K.T., E. Saputro. 2013. Sebaran Spasial Foraminifera dalam Kaitannya dengan Kedalaman Laut dan Jenis Sedimen di Teluk Bone, Sulawesi Selatan. J. Geologi Kelautan 11(3): 165-174. 
Drinia, H., A. Antonarakou, N. Tsaparas. 2004. Diversity and Abundance Trends of Benthic Foraminifera from The Southern Part of The Iraklion Basin, Central Crete. Bulletin of The Geological Society of Greece 15: 772-781.

Geslin, E., J.P. Debenay, W. Duleba, and C. Bonetti. 2002. Morphological Abnormalities of Foraminiferal Tests in Brazilian Environments: Comparison Between Polluted and Non-Polluted Areas. J. Marine Micropalaentology 45: 151-168.

Gustiani, L., K.T. Dewi, E. Usman. 2005. Foraminifera di Perairan Sekitar Bakauheni, Lampung (Selat Sunda Bagian Utara). J. Geologi Kelautan 3(1): 1018.

Gustiani, L., E. Usman. 2008. Distribusi Foraminifera Bentik sebagai Indikator Kondisi Lingkungan di Perairan Sekitar Pulau Batam-Riau Kepulauan. J. Geologi Kelautan 6(1): 43-52.

Hallock, P., B.H. Lidz, E.M. Cockey-Burkhard, K.B. Donnelly. 2003. Foraminifera a Bioindicators in Coral Reef Assessment and Monitoring: The Foram Index. Enviromental Monitoring and Assessment J. 18: 221-238.

Loeblich, R., Tappan. 1994. Foraminifera of The Sahul Shelf and Timor Sea. Departement of Earth and Space Sciences. University of California. Los Angeles.

Mendes, I., R. Gonzalez, J.M.A. Dias, F. Lobo, V. Martins. 2004. Factors Influencing Recent Benthic Foraminifera Distribution on The Guardiana Shelf (Southwestern Iberia) J. Marine Micropaleontology 51: 171-192.

Mojtahid, M., F. Jorrisen, J. Durrieu, F. Galgani, H. Howa, F. Redois, R. Camps. 2006. Benthic Foraminifera as Bioindicators of Drill Cutting Disposal in Tropical East Atlantic Outer Shelf Environments. J. Marine Micropalaentology 61(13): $58-75$.

Murray, J.W. 2006. Ecology and Application of Benthic Foraminifera. Cambridge University Press: Cambridge.

Natsir, S.M. 2010. Distribusi Foraminifera Bentik Resen di Perairan Lombok. Biosfera 27(2): 95-102.

Nooijer, L.J., G. Langer, G. Nehrke, J. Bijma. 2009. Physiological Controls on Seawater Uptake and Calcification in The Benthic Foraminifer Ammonia tepida. Biogeosciences 6: 2669-2675.
Noortiningsih, I.S. Jalip, S. Handayani. 2008. Keanekaragaman Makrozoobentos, Meiofauna, dan Foraminifera di Pantai Pasir Putih Barat dan Muara Sungai Cikamal Pangandaran, Jawa Barat. Vis Vitalis 1(1): 34-42.

Nurruhwati, I., Kaswadji, R., Bengen, D.G., Isnaniawardhani. 2012. Kelompok Foraminifera Bentik Resen Berdasarkan Komposisi Dinding Cangkang di Perairan Teluk Jakarta. J. Akuatik 3(2): 190-197.

Renema, W. 2008. Habitat Selective Factors Influencing The Distribution of Larger Benthic Foraminiferal Assemblages Over The Kepulauan Seribu. Marine Micropaleontology 68: 286-298.

Rositasari, R. 2006. Komposisi Jenis Foraminifera dan Kemunculan Cangkang Abnormal pada Ammonia beccarii di Teluk Jakarta Sebagai Indikator Lingkungan Tercemar. J. Ilmu Kelautan 11(2) : 1-5.

Rositasari, R. 2011. Karakteristik Komunitas Foraminifera di Perairan Teluk Jakarta. J. Ilmu dan Teknologi Kelautan Tropis 3(2): 100-111.

Toruan, L.N.L., D. Soedharma, K.T. Dewi. 2013. Komposisi dan Distribusi Foraminifera Bentik di Ekosistem Terumbu Karang pada Kepulauan Seribu. J. Ilmu dan Teknologi Kelautan Tropis 5(1): 1-16.

Vilela, C.G., D.S. Batista, J.A.B. Neto, M. Crapez, J.J. Mcallister. 2004. Benthic Foraminifera Distribution in High Polluted Sediments from Niteroi Harbor (Guanabara Bay), Rio de Jenerio, Brasil. J.of Anais da Academia Brasileira de Ciencias 76(1): 161-171.

www.ppkkp3k.kkp.go.id/ver3/media/download/RE_ke putusan-menteri-negara-lingkungan-hidup-nomor51-tahun-2004_20141008143942. 2012. Keputusan Menteri Lingkungan Hidup 2004, [Online]. Available:"http://www.ppkkp3k.kkp.go.id/ver3/me dia/download/RE keputusan-menteri negara lingkungan-hidup-nomor-51-tahun2004_20141008143942"[12 November 2016].

Yamano, H., T. Miyajima, I. Koike. 2000. Importance of Foraminifera for The Formation and Maintenance of a Coral San Cay : Green Island, Australia. Coral Reefs 18: 51-58.

Yassini, I., B.G. Jones. 1995. Foraminifera and Ostracoda From Estuarine and Shelf Enviroments On The Southeastern Coast of Australia. Australia. 